\title{
Application of Theory of Planned Behavior on the Implementation of the Emo Demo Creation of Healthy PMT with Full Nutrition in Posyandu Gedang - Gedang Village Batuputih Sumenep
}

\author{
Asri Rengganis ${ }^{1}$, Katmini $^{2}$ \\ ${ }^{1}$ Public Health Center Batuputih \\ ${ }^{2}$ Master of Public Health, \\ Institute of Health Sciences \\ STRADA Indonesia \\ Email: \\ asrirengganis21@gmail.com
}

Received : October $4^{\text {nd }} 2021$

Accepted : October $15^{\text {rd }} 2021$

Published : November $27^{\text {th }} 2021$

\begin{abstract}
Efforts to improve nutrition with healthy food consumption patterns require an derstanding of variations or training in appropriate cooking practices that are liked by the family. The purpose of developing a health promotion model by implementing an emo demo made from local food through the Theory Planned Behavior approach at the posyandu. Analytical research with cross sectional design. The independent variables are intentions, behavior, attitudes, norms and the dependent variable is the implementation of emo demo creations of healthy nutritious PMT. The population of all mothers in posyandu is 150 people, the sampling technique using random sampling is 115 people. The research instrument used a questionnaire with classical assumption test and multiple linear regression data analysis using $\mathrm{T}$ test and F sig $<0.05$, the result of $0.039 \mathrm{HI}$ was accepted, which means that there is an influence of the theory of planned behavior with the implementation of healthy and complete PMT. The conclusion is that the development of health in the field of nutrition with the emo demo method can increase understanding in the form of stories, interesting with visuals, with observation modalities that are safe for consumption and directly stimulate emotional so that changes in health behavior occur.
\end{abstract}

Keywords: Emo demo, theory of planned behavior, local based PMT

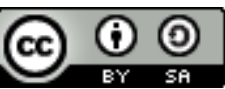

This is an open-acces article distributed under the terms of the Creative Commons AttributionShareAlike 4.0 International License.

\section{INTRODUCTION}

Standard health efforts are a series of activities carried out in an integrated, integrated and sustainable manner to maintain and improve the health status of the community in the form of disease prevention, health improvement, disease treatment and health recovery by the government and or the community. The success of the empowerment process can be seen by the realization of various community-based health efforts (UKBM) in the community. UKBM is a community-based health effort formed from, by, for and with the community, including posyandu(Harsono dr, 2013). 
Application of Theory of Planned Behavior on the Implementation of the Emo Demo Creation.....

An indicator of the low level of community participation in posyandu is the lack of variety of PMT counseling which is often one of the causes of the reduced attendance rate of mothers of children under five coming to the Posyandu. Giving the right PMT to infants and children will help in the process of growth and development(Andarwulan \& Hubaedah, 2020).

Additional food can be the main attraction for a mother to come to the Posyandu, so that more targets will come (Hidayanti and Maywati, 2019). (Prihandini et al., 2013)when toddlers have difficulty eating or have no appetite for the food served. Most of the elderly in the village often provide fast food, with packaged snacks without any effort to contribute to healthy food processing and they are too busy with daily activities.(Bahtiar \& Ariyanti, 2017).

Based on data from the Sumenep District Health Office in 2018, the number of pregnant women with KEK was 49 people and the number of BGM toddlers was 17 toddlers with an achievement of $0.86 \%$ with a target of $15 \%$. In 2020, Gedang-Gedang Village and Badur Village, Batuputih Subdistrict, became the locus of stunting because the number of stunting in these villages was considered higher than other villages in Batuputih District, with the number of toddlers stunting in Gedanggedang Village as many as 6 toddlers and Badur Village as many as 3 toddler.

Efforts made to change behavior include cross-sectoral collaboration between the village head who facilitates demonstration activities so that it can continue, the village PKK as an effort to empower the community, B2SA trainers, community leaders, and religious leaders. Through cross programs for nutrition officers to make examples of interesting menus, inviting PKM employees who have expertise in cooking, the puskesmas held training for posyandu cadres on nutrition.

\section{METHOD}

The research conducted in March is a quantitative study located in the village of Gedang Gedang with a total of 4 posyandu consisting of the Tambaraan Posyandu, Gunung Papan Posyandu, Tanjung Posyandu and Posyandu totaling 150 people, the design used random sampling so that the sample obtained was 115 people (mother, mothers of infants, pregnant women). The instrument used is a questionnaire. The analysis used univariate to describe the characteristics of respondents, bivariate aims to reveal the relationship of independent variables with the Theory Of Planned Behavior approach, namely intentions, behavior, attitudes and norms towards the implementation of emo demo creations of healthy nutritious PMT, and multivariate with multiple linear regression test.Prior to the implementation of the research activity, coordination with the Village Head, the head of the Village PKK TP and the Village Health Officer were asked for assistance to be involved in these activities. 
Application of Theory of Planned Behavior on the Implementation of the Emo Demo Creation.....

\section{RESULT}

Univariate Analysis

Table 1. Distribution of Characteristics of Respondents by Age, Last Education, Occupation, Income, in Gedang - Gedang Batuputih Village

\begin{tabular}{|c|c|c|c|}
\hline No. & Characteristics & F & $\%$ \\
\hline 1. & $18-25$ years old & 40 & 34.8 \\
\hline 2. & SD & 42 & 36.5 \\
\hline 3. & farmer & 108 & 93.9 \\
\hline 4. & $<$ Rp. $1,000,000.00$ & 114 & 99.1 \\
\hline
\end{tabular}

The response to the same stimulus but the response also depends on each person differently, the factors that distinguish the response to different stimuli are called behavioral determinants. Behavioral determinants can be divided into two, namely:

a. Determinants or internal factors such as the characteristics of respondents that are given or innate such as gender.

b. External determinants or factors, namely the physical, social, economic environment and so on

With the characteristics of the respondents in terms of the age group, most of the respondents are aged 18 - 24 years, as many as 40 respondents (34.8\%) in that age interval are productive ages and are identical with high idealism, increased work spirit and full of optimism.

The respondent's last education was elementary school 36.5\%. A person's education directly affects knowledge, although it is not the same as his field of knowledge. According to (Notoatmodjo, 2012) a person's knowledge can be influenced by various factors, one of which is education. The higher the education, the person will have wider access to information through various print and electronic media. Mothers who do not work are more passive in getting information, such as watching television(Freisling et al., 2010).

Based on the occupations of 108 respondents (93.9\%) most of the Posyandu mothers (cadres, pregnant women, breastfeeding mothers) are farmers. In the sense of spending time at home as a housewife and farming. Wage salary or income of respondents $<$ Rp 1,000,000 per month is a reward given to someone after doing work. Income is generally in the form of money or other material. The amount of income received by a person reflects the size of life in meeting basic daily needs. If the income they receive is adequate, the need for adequate nutrition in the family will increase. The economy has an effect (enabling/enabling factor) on increasing public access to higher education.It has been demonstrated that stunting has long-term adverse consequences for children's immune function and survival, risk of chronic disease related to nutrition, cognitive and behavioral 
development, and human capital (educational attainment and economic productivity). (Norris et al., 2014). Characteristics supported by

Univariate Analysis

Table 1. Distribution of Characteristics of Respondents by Age, Last Education, Occupation, Income, in Gedang - Gedang Batuputih Village

\begin{tabular}{|c|c|c|c|}
\hline No. & Characteristics & F & $\%$ \\
\hline 1. & $18-25$ years old & 40 & 34.8 \\
\hline 2. & SD & 42 & 36.5 \\
\hline 3. & farmer & 108 & 93.9 \\
\hline 4. & $<$ Rp. $1,000,000.00$ & 114 & 99.1 \\
\hline
\end{tabular}

The response to the same stimulus but the response also depends on each person differently, the factors that distinguish the response to different stimuli are called behavioral determinants. Behavioral determinants can be divided into two, namely:

a. Determinants or internal factors such as the characteristics of respondents that are given or innate such as gender.

b. External determinants or factors, namely the physical, social, economic environment and so on

With the characteristics of the respondents in terms of the age group, most of the respondents are aged 18 - 24 years, as many as 40 respondents (34.8\%) in that age interval are productive ages and are identical with high idealism, increased work spirit and full of optimism.

The respondent's last education was elementary school 36.5\%. A person's education directly affects knowledge, although it is not the same as his field of knowledge. According to (Notoatmodjo, 2012) a person's knowledge can be influenced by various factors, one of which is education. The higher the education, the person will have wider access to information through various print and electronic media. Mothers who do not work are more passive in getting information, such as watching television(Freisling et al., 2010).

Based on the occupations of 108 respondents (93.9\%) most of the Posyandu mothers (cadres, pregnant women, breastfeeding mothers) are farmers. In the sense of spending time at home as a housewife and farming. Wage salary or income of respondents $<$ Rp 1,000,000 per month is a reward given to someone after doing work. Income is generally in the form of money or other material. The amount of income received by a person reflects the size of life in meeting basic daily needs. If the income they receive is adequate, the need for adequate nutrition in the family will increase. The economy has an effect (enabling/enabling factor) on increasing public access to higher education.It has been demonstrated that stunting has long-term adverse consequences for children's immune function and survival, risk of chronic disease related to nutrition, cognitive and behavioral development, and human capital (educational attainment and economic productivity). (Norris et al., 
2014). Characteristics supported by(Dewi \& Yenni Latrini, 2020)in the influence of socio-economic factors and materialism on personal financial behavior through financial literacy accounting materialism that several factors are suspected to have a direct and indirect influence on an individual's ability to manage finances. One of these factors is the socioeconomic status of parents. The socioeconomic status of parents as measured by income or parental income provides a direction for financial management education in the family. Differences in the socioeconomic status of parents bring big differences in the upbringing of children. Children are conditioned by subculture and economic class which in turn influences their behavior.

Bivariate Analysis

Table 2. Analysis of the relationship between variables (T test) Intentions, Behaviors, Attitudes, Norms with Emo Demo creations of healthy and complete PMT

\begin{tabular}{rcccc}
\hline Variable & B (Coefficient) & Beta & Tcount & Sig t \\
\hline Intention (X1) & -0.159 & -0.162 & -1.451 & 0.150 \\
\hline Behavior (X2) & 0.185 & 0.222 & 1996 & 0.048 \\
\hline Attitude (X3) & -0.051 & -0.063 & -0.565 & 0.573 \\
\hline Norm (X4) & 0.242 & 0.242 & 2.296 & 0.024 \\
\hline
\end{tabular}

Table 2. There is no relationship between the intention variable and the sig value of $0.150>0.05$, which means that there is no relationship between the intention variable and the posyandu mother to participate in the implementation of the emo demo.

Table 2. This study reveals that the intention value of sig $0.048<0.05$ is an indication of how strong a person's belief is that he will try a behavior and how much effort will be used to carry out a respondent's behavior with good behavior to come to the posyandu following PMT's emo demo creation. complete nutrition and can make home cooking according to the example.

Table 2. Based on the attitude of the respondents, the value of sig $0.573>0.05$ with a significance so that it can be concluded that there is no positive relationship to the implementation of emo demo creations of healthy and complete PMT creations

Table 2. Based on the research results, the majority of respondents have a high subjective norm, a sig value of $0.024<0.05$. The family is a reinforcing factor in the formation of behavior, including children's eating behavior. Parents are considered the main key in understanding and applying values and principles first to children. 
Application of Theory of Planned Behavior on the Implementation of the Emo Demo Creation.....

Multivariate Analysis

Table 3. Results of Simultaneous Significance (Test F) Analysis of the Application of Theory Of Planned Behavior on the Implementation of the Emo Demo Creation of Healthy and Completely Nutritious PMT in Posyandu

\begin{tabular}{|c|c|c|c|c|c|c|}
\hline \multicolumn{2}{|c|}{ Model } & Sum of Squares & df & Mean Square & F & Sig. \\
\hline \multirow{2}{*}{ Regression } & 452.889 & 4 & 113.222 & 2,617 & $.039 \mathrm{a}$ \\
\cline { 2 - 7 } & Residual & 4759,685 & 110 & 43.270 & & \\
\cline { 2 - 7 } & Total & 5212,574 & 114 & & & \\
\hline
\end{tabular}

Table 4.3 shows simultaneous significant results (F test) Multiple Linear Regression analysis sig value $0.039>0.05$ independent variable theory planned behavior consisting of Intention (X1), Behavior (X2), Attitude (X3) and Norm (X4) there is a relationship with the dependent variable the implementation of the emo demo creation of a complete nutritious healthy PMT (Editansil).

\section{DISCUSSION}

Partial T-test shows that intentions and attitudes have no relationship with the implementation of a complete nutritious healthy PMT emo demo that can occur because: looking at the characteristics of elementary school education, work, monthly income is below the standard, it makes the factor of not being able to trust, belief, benefits attached to his conscience which cannot be seen directly by the eye, the number of emo demo implementation meetings which are still relatively rarely practiced in posyandu so that with low education mothers still find it difficult to adopt new knowledge, in terms of active participation mothers come to posyandu on time for invitations before implementation of emo demo begins or comes after the implementation of the emo demo is complete, looking at the mother's attention to the implementation of the emo demo, whether listening while talking to her friends,or while caring for a fussy child

While the Partial $\mathrm{T}$ Test of behavior and norms has a relationship with the implementation of the emo demo creations of healthy and complete PMT, it can be caused by several factors, including that respondents see that emo demos are easy to do and the availability of raw materials from local products from home yards that can be combined with several ingredients in the market. village. Support from social media such as cellphones can be a motivation to be creative because it is seen from the characteristics of respondents who are still productive. With the support of other people, friends, religious leaders, community leaders and activities every month is always repeated with a different theme.

Based on this study, it was found that the F test simultaneously showed a relationship between the theory of planned behavior (intentions, behavior, attitudes, norms) and the emo demo creations of healthy PMT with complete nutrition. The implementation of the planned emo demo which is packaged in the form of a story that is easy to remember, interesting, with observational modalities 
Application of Theory of Planned Behavior on the Implementation of the Emo Demo Creation.....

(feeling / tasting, smelling / smelling, and touching) is safe for consumption by children and families so that it immediately stimulates the emotional reaction of posyandu mothers. Making examples of nutritious food using local plants combined in a simple way can immediately be practiced in everyday life. Every month at the posyandu, Gedang Gedang village serves a different menu. Due to the sake of increasing knowledge, there can be changes after intervention by health promotion officers using the emo demo method.

\section{CONCLUSION}

With Theory Planned Behavior to find out intentions, behaviors, attitudes, norms through BCD Behavior Communication Definition states that an intervention can change something in the environment and Social Behavior Change Communication (SBCC) / Communication on Social and Behavioral Changes SBCC can be a mother's facility by empowering cadres, community leaders, religious leaders, in understanding, adopting and maintaining healthy behaviors related to nutrition practices. Respondents in this study were cadre mothers, pregnant women, breastfeeding mothers, the majority of whom were of productive age, which was based on a low level of education, limited employment and income, simultaneously determinants of health behavior from experience, environmental beliefs, socio-culture that influenced knowledge, perception, attitude, desire, will, motivation and intention. In health promotion activities in the field of nutrition using the implementation method with planned emo demo activities packaged with interesting stories that are easy to remember and safe for consumption can stimulate emotional reactions indicating a change in mother's perception towards better behavior changes. .

\section{REFERENCES}

217754972-juknis-guidance-technical-implementation-emodemo-at-park-posyandu.pdf.pdf. (nd).

Adventus, Jaya, IMM, \& Mahendra, D. (2019). Health Promotion Textbook. Center for Health HR, (1), 6-8.

Amareta, DI, \& Ardianto, ET (2017). Health Extension with the Emo Demo Method Effectively Improves CTPS Practice at MI Al-Badri Kalisat, Jember Regency. 246-250.

Bahtiar, H., \& Ariyanti, M. (2017). BEST PARENTING-PARENTS TO DIET AND FOODCONSUMPTION ON TODDLERS.

Dewi, LGK, \& Yenni Latrini, M. (2020). The Influence of Socio-Economic Factors and Materialism on Personal Financial Behavior through Financial Literacy of Accounting Students. E-Jurnal Accounting, 30(6), 1575. https://doi.org/10.24843/eja.2020.v30.i06.p18

Freisling, H., Haas, K., \& Elmadfa, I. (2010). Mass media nutrition information sources and associations with fruit and vegetable consumption among adolescents. Public Health Nutrition, 13(2), 269-275. https://doi.org/10.1017/S1368980009991297

Harjadmo, TP (2017). NUTRITIONAL ASSESSMENT TEACHING MATERIALS (PE MOLD). CENTER FOR HEALTH HUMAN RESOURCES EDUCATION AGENCY FOR HEALTH HUMAN RESOURCES DEVELOPMENT AND EMPOWERMENT AGENCY OF HEALTH MINISTRY OF HEALTH OF THE REPUBLIC OF INDONESIA.

Harsono dr. (2013). Health Center Standards for Health Service Development, East Java Provincial Health Office.

Hidayanti, L.-, \& Maywati, S.-. (2019). Community Partnership Program: Pmt Local Food Extension 
in Sukarame Village, Sukarame District, Tasikamalaya Regency, West Java. LPM News, 21(2), 31-39. https://doi.org/10.23917/warta.v21i2.7048

Hidayanti, L., Maywati, S., Health, FI, \& Siliwangi, U. (2018). Nutrition Promotion Mela L Ui Method Emo Demo For.

Hoddinott, J., Ahmed, I., Ahmed, A., \& Roy, S. (2017). Behavior change communication activities improve infant and young child nutrition knowledge and practice of neighboring nonparticipants in a cluster-randomized trial in rural Bangladesh. PLoS ONE, 12(6), 1-13. https://doi.org/10.1371/journal.pone.0179866

Kustiani, A., \& Misa, AP (2018). Changes in Knowledge, Attitudes, and Behavior of Mothers in Giving Breastfeeding to Children aged 6-24 Months in Nutrition Counseling Interventions in Lubuk Buaya, Padang City. PIONEER'S HEALTH JOURNAL (Pioneer's Health Journal), 5(1), 51-57. https://doi.org/10.33653/jkp.v5i1.94

Norris, SA, Wrottesley, S., Mohamed, RS ai., \& Micklesfield, LK (2014). Africa in transition: growth trends in children and implications for nutrition. Annals of Nutrition \& Metabolism, 64, 8-13. https://doi.org/10.1159/000365122

Notoatmodjo, S. (nd). No Title health research methodology (2012th ed.). creative mix.

Paroche, MM, Caton, SJ, Vereijken, CMJL, Weenen, H., \& Houston-Price, C. (2017). How infants and young children learn about food: A systematic review. Frontiers in Physiology, 8(JUL). https://doi.org/10.3389/fpsyg.2017.01046

Prihandini, M., Iswanti, DI, \& Umariyah, SN (2013). Demonstration and Leaflet Method on Mother's Motivation at Posyandu Kunthisari Jetak, Semarang Regency. Journal of Midwifery, V(02), 5765.

Prof.Dr. Soekidjo Notoatmodjo. SKM, MCH (2012). Health Promotion and Health Behavior (revised 2012 edition). In Jakarta: rineka copyright.

Purwanti, D. (2020). The Emo-Demo Method Is An Effective Method In Preventive Behavior Change In Early Marriage Of Young Women. 11, 101-106. http://dx.doi.org/10.33846/sf11nk417\%0A

Sinclair, R., Millar, L., Allender, S., Snowdon, W., Waqa, G., Jacka, F., Moodie, M., Petersen, S., \& Swinburn, B. (2016). The cross-sectional association between diet quality and depressive symptomology amongst Fijian teenagers. PLoS ONE, 11(8), 1-12. https://doi.org/10.1371/journal.pone.0161709

Wang, L., Van De Gaar, VM, Jansen, W., Mieloo, CL, Van Grieken, A., \& Raat, H. (2017). Feeding styles, parenting styles and snacking behavior in children attending primary schools in multiethnic neighborhoods: A cross-sectional study. BMJ Open, 7(7). https://doi.org/10.1136/bmjopen-2016-015495

authority. et al. (2014). Implementation of Health Promotion Policy (Study at Dinoyo Community Health Center, Lowokwaru District, Malang City). Brawijaya University Student Public Administration Journal, 2(11), 1-5. 